\title{
ATOMIC ABSORPTION AND FLAME EMISSION SPECTROSCOPY ANALYSES OF BASALT CORE SAMPLES AND WATER SAMPLES FROM A DEEP WELL
}

By

\author{
M. J. Kupfer
}

\section{Separations Chemistry Laboratory \\ Research and Development Chemical Processing Division}

\section{LEGAL NOTICE}

This report was prepared as an account of work sponsored by the United States Government. Neither the United States nor the United States Atomic Energy the United States nor the their employees, nor any of Commission, nor any of their employees, their contractors, subcontractors, or their explos or assumes any makes any warranty, express or implied, or assumes any legal liability or responsibility for the accuracy, completeness or usefulness of any in represents that its use product or process disclosed, or represents
would not infringe privately owned rights.

\section{ATLANTIC RICHFIELD HANFORD COMPANY}

RICHLAND, WASHINGTON 


\section{DISCLAIMER}

This report was prepared as an account of work sponsored by an agency of the United States Government. Neither the United States Government nor any agency Thereof, nor any of their employees, makes any warranty, express or implied, or assumes any legal liability or responsibility for the accuracy, completeness, or usefulness of any information, apparatus, product, or process disclosed, or represents that its use would not infringe privately owned rights. Reference herein to any specific commercial product, process, or service by trade name, trademark, manufacturer, or otherwise does not necessarily constitute or imply its endorsement, recommendation, or favoring by the United States Government or any agency thereof. The views and opinions of authors expressed herein do not necessarily state or reflect those of the United States Government or any agency thereof. 


\section{DISCLAIMER}

Portions of this document may be illegible in electronic image products. Images are produced from the best available original document. 
Printed in the United States of America Available from

Clearinghouse for Federal Scientific and Technical Information National Bureau of Standards, U. S. Department of Commerce Springfield, Virginia 22151

Price: Printed Copy $\$ 3.00 ;$ Microfiche $\$ 0.65$ 


\section{TABLE OF CONTENTS}

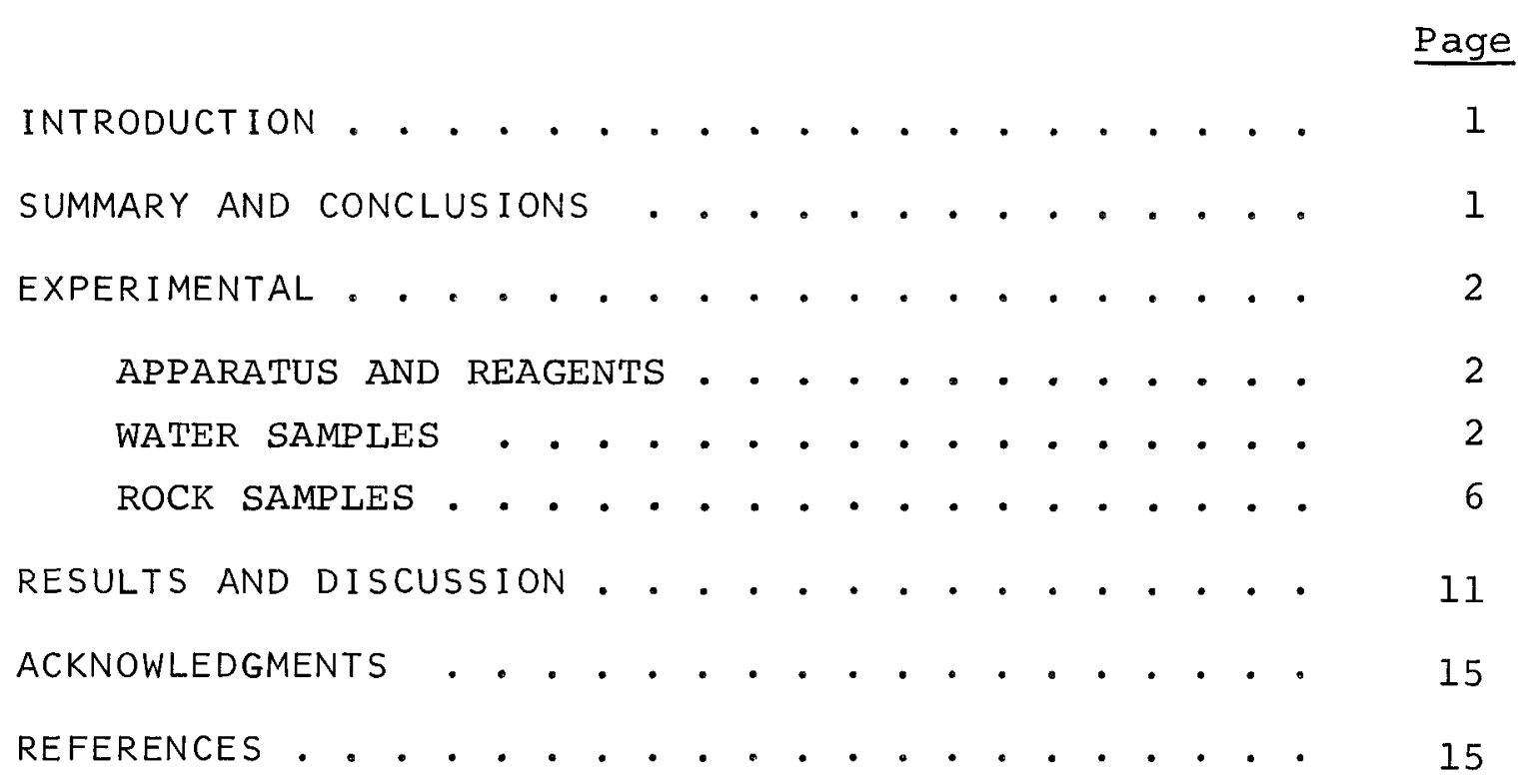




\section{ABSTRACT}

Atomic absorption was found to be a fast and accurate method for determining the major metal oxides and several trace elements in basaltic rock flows. Rock samples were fused with lithium metaborate, then dissolved with dizute hydrochloric acid. Trace elements as well as the major constituents were easily analyzed from the fusion solution. Experimentation also showed that a treatment of this solution with ion exchange folzowed by a dithizone-ethyz propionate extraction enabled a 15-fold improvement in the detection limits of $\mathrm{Pb}, \mathrm{CO}, \mathrm{Cu}$, and $N i$.

Water samples were successfulzy analyzed by atomic absorption and flame emission for 19 elements. Determinations were made directly or from dizutions of the samples. Several trace elements of very low concentrations were chelated with ammonium pyrollidine dithiocarbamate and extracted into methy isobutyl ketone. This extraction effectively improved detection limits of the elements up to 30-fold. 


\begin{abstract}
ATOMIC ABSORPTION AND FLAME EMISSION SPECTROSCOPY ANALYSIS OF BASALT CORE SAMPLES AND WATER SAMPLES FROM A DEEP WELL
\end{abstract}

\title{
INTRODUCTION
}

In April, 1969, Atlantic Richfield Hanford Company (ARHCO) began drilling an exploratory deep well near the 200-East Area at the U.S. Atomic Energy Commission's Hanford site. The purpose of the well was to become familiar with the composition patterns of the various basaltic flows which are present in this area. This knowledge would, in turn, enable comparison of the basaltic flows with earlier exploratory wells.

A method which would provide fast, reliable results for the major and minor elements was needed for analysis of both well water and basalt core samples. Atomic absorption and flame emission have recently proven capable of similar tasks. In the past five years, atomic absorption in particular has proved to be highly sensitive and relatively free from interferences even in complex solutions. In addition, both techniques are rapid--and at the same time produce high-precision results. For these reasons, atomic absorption and flame emission spectroscopy were chosen as tools for the task.

\section{SUMMARY AND CONCLUSIONS}

An analytical scheme was developed which enabled dissolution and analysis of 18 elements at both major and trace concentrations in the basaltic core samples. In addition, a scheme of analysis for water samples was prepared which allowed determination of 19 elements--several of which were in the parts per billion range. 
The results showed that atomic absorption and flame emission may be used exclusively to provide reliable results on both water and basalt core samples for the major constituent elements and many trace elements. Sample preparation is minimal; interferences are rare, especially with the atomic absorption mode. Analytical range is very broad and precision is generally good.

\section{EXPER IMENTAL}

\section{APPARATUS AND REAGENTS}

A Varian Techtron AA5 Atomic Absorption Unit was used for all of the analyses. Results were recorded from a digital indicator either in absorbance or directly in concentration.

Reagent grades of lithium metaborate $\left(\mathrm{LiBO}_{2}\right)$, methyl isobutyl ketone (MIBK), ammonium pyrollidine dithiocarbamate (APDC), dithizone, ethyl propionate, and lanthanum nitrate (99.997 percent) were used.

\section{WATER SAMPLES}

After their removal from the ground, water samples were immediately acidified with 10 milliliters of concentrated hydrochloric acid per gallon of water. This prevented precipitation of ferric hydroxide.

For several elements the sample was analyzed directly. When dilutions were required, they were made into small, plastic, 15-ml screw-cap vials containing the proper diluent. Sodium, magnesium, and calcium were found to be leached from glass vials into the diluent on long periods of standing.

The analytical scheme used for water samples is described in Table I, page 3. This table summarizes dilutions and instrumental parameters. 
TABLE I

SUMMARY OF ANALYTICAL AND INSTRUMENTAL

PARAMETERS FOR AA MEASUREMENTS ON WATER SAMPLES

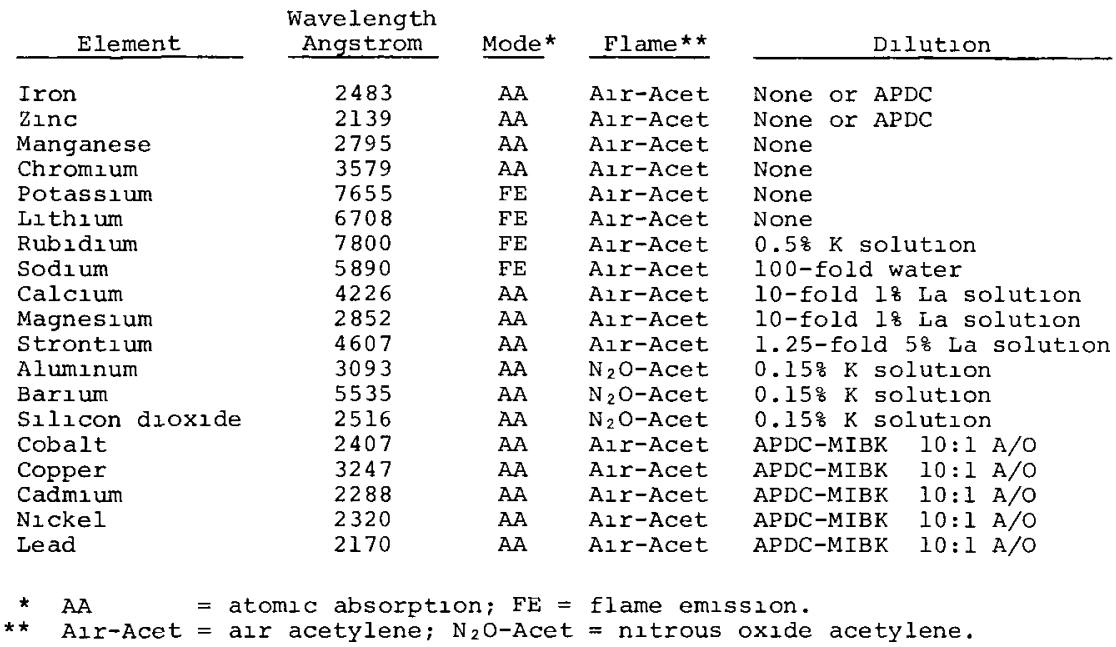

\section{Iron, Zinc, Manganese, and Chromium}

Concentrations of $\mathrm{Fe}, \mathrm{Zn}, \mathrm{Mn}$, and $\mathrm{Cr}$ were such that they could be directly determined. These samples were compared with simple aqueous standards by atomic absorption using an air-acetylene flame. Where iron or zinc concentrations were very low, analyses were made after chelation with APDC and extraction into MIBK. This procedure is described further on page 5. Manganese and chromium were usually found in very low concentrations, but could not be determined by the organic extraction as the presence of other metals (especially iron) tended to inhibit their extraction.

\section{Lithium, Rubidium, and Potassium}

Lithium, rubidium, and potassium were analyzed directly by using flame emission. In all cases an air-acetylene flame 
was used with a 10-cm burner. For lithium analysis, sodium was added to the standards at a concentration equal to that present in the sample. Slight interference was observed from the presence of large amounts of sodium. Rubidium sensitivity was enhanced about 5-fold by the presence of excess potassium, which permits an increase in neutral $\mathrm{Rb}$ atoms in the flame. (1) Consequently, all samples to be analyzed for rubidium were spiked with enough potassium to provide an 0.5 percent potassium solution. Potassium-containing standards and a potassium blank were prepared to compare with the samples.

Magnesium, Calcium, and Strontium

Magnesium and calcium were determined by atomic absorption after diluting the sample 10-fold into a 1 percent lanthanum solution.

In all cases lanthanum is present to act as a releasing agent for $\mathrm{Ca}, \mathrm{Sr}$, and $\mathrm{Mg}$ from the inhibiting effects caused by interfering components. (2)

Sodium

Sodium concentration in the water samples was generally very high. In most cases a 100-fold dilution was made and flame emission was used for the determination.

Aluminum, Barium, and Silicon

These elements were determined by atomic absorption after addition of sufficient potassium to produce an 0.15 percent potassium solution. A nitrous oxide-acetylene flame was used. The potassium is present to prevent ionization interferences ( ${ }^{3}$ ) in the cases of aluminum and barium. 
Cobalt, Copper, Cadmium, Lead, Iron, Zinc, and Nickel

These elements were chelated with ammonium pyrollidine dithiocarbamate (APDC) and all were quantitatively extracted at one time into methyl isobutyl ketone (MIBK). The elements were determined using atomic absorption; the organic phase was aspirated into an air-acetylene flame. Using an aqueousto-organic ratio of 10 to 1 , the detection limit was increased about 30-fold with this method. The absorbances were compared against reference standards prepared by the same method as the samples. The reference standards consisted of aqueous solutions synthesized to contain 10 times the typical sample concentrations of the major metals plus known amounts of various trace elements. When it was necessary to run a sample, a portion of the standards were diluted 10-fold with demineralized water before being chelated and extracted into MIBK. Two reference standards were used; and, after 10-fold dilution, contained the following: $150 \mathrm{ppm}$ sodium, $3 \mathrm{ppm}$ calcium, $0.25 \mathrm{ppm}$ magnesium, 0.1 and $0.2 \mathrm{ppm}$ iron, 0.012 and $0.025 \mathrm{ppm}$ zinc, 0.1 and $0.2 \mathrm{ppm}$ nickel, 0.1 and 0.2 lead, 0.1 and $0.2 \mathrm{ppm}$ cobalt, 0.05 and $0.1 \mathrm{ppm}$ copper, and 0.012 and $0.025 \mathrm{ppm}$ cadmium.

In a typical analysis of well water using organic extraction, $500 \mathrm{ml}$ of well water sample were poured into a clean, one-liter separatory funnel and $10 \mathrm{ml}$ of fresh 2 percent APDC solution were added. The solution was shaken for 10 seconds, after which $50 \mathrm{ml}$ of MIBK were added. The solution was then shaken for 10 minutes to allow extraction of the chelates into the MIBK layer. The reference standards were diluted 10-fold from 50 milliliters with demineralized water, and treated as above. The organic MIBK layer was analyzed for the various metals using as a blank pure MIBK which was previously pre-equilibrated with water.

In those samples where iron was quite high $(0.5 \mathrm{ppm}$ or 
morel; it was necessary to perform a second extraction on the aqueous. The large amount of iron interfered with the chelation of some of the other trace elements. If the first extraction was visually found to contain large amounts of blackcolored iron chelate, $10 \mathrm{ml}$ more of 2 percent APDC were added to the aqueous and the solution was extracted with $25 \mathrm{ml}$ of MIBK. The first and second extracts were then combined for analysis.

\section{$\underline{\text { ROCK SAMPLES }}$}

Dissolution

The crushed core samples were prepared for analysis by fusion with lithium metaborate $\left(\mathrm{LiBO}_{2}\right)$. This technique, described by Yule and Swanson, (4) proved to be short, provided high precision, and allowed little chance for introduction of contamination.

In this dissolution procedure, 400 milligrams of 100 mesh crushed sample were heated at $800 \mathrm{C}$ for 10 minutes to drive off the volatiles. After cooling and reweighing, the percent volatiles was recorded. The sample was then mixed in a platinum crucible with 2 grams of $\mathrm{LiBO}_{2}$. This mixture was fused for 15 minutes in a furnace at $1000 \mathrm{C}$. The crucible was removed from the furnace and placed into a 400-ml Pyrex beaker. Thirty seconds after removal from the furnace, approximately $100 \mathrm{ml}$ of hot, 10 percent hydrochloric acid solution were poured into the crucible and the solution was stirred and heated until the fusion melt was dissolved. Additional 10 percent $\mathrm{HCl}$ was added if crystallization occurred. A watch glass was kept over the beaker at all times to prevent evaporation. After cooling, the solution was brought to $200 \mathrm{ml}$ total volume with 10 percent HCl. All dilutions were made from the fused solution into 15-ml glass or plastic vials.

The United States Geological Survey (USGS) BCR-1 and 
USGS $W-1$ crushed rock samples were used as control references for basalt analyses. These samples were dissolved and analyzed by the same procedure as the well core samples.

All basalt analyses were made by reading five basic dilutions of the fusion solutions against standards. For several elements it was necessary to read the fusion solution directly. The analytical scheme is presented below. Table II summarizes dilutions and instrumental parameters.

TABLE II

ANALYTICAL SUMMARY FOR FUSION SOLUTION

OF BASALT ROCK SAMPLES

\begin{tabular}{|c|c|c|c|c|c|}
\hline Element & $\frac{\text { Wave length }}{\text { Angstrom }}$ & Mode** & Flame ${ }^{\star \star}$ & & Dilution \\
\hline $\begin{array}{l}\text { Aluminum } \\
\text { Silicon }\end{array}$ & $\begin{array}{l}3093 \\
2516\end{array}$ & $\begin{array}{l}A A \\
A A\end{array}$ & $\begin{array}{l}\mathrm{N}_{2} \mathrm{O} \text {-Acet } \\
\mathrm{N}_{2} \mathrm{O} \text {-Acet }\end{array}$ & 1) & $\begin{array}{l}\text { l-ml sample and } 500 \lambda 10 \% \\
\mathrm{KCl}+10 \mathrm{ml} \mathrm{H}_{2} \mathrm{O} .\end{array}$ \\
\hline $\begin{array}{l}\text { Calcium } \\
\text { Magnesium }\end{array}$ & $\begin{array}{l}4226 \\
2852\end{array}$ & $\begin{array}{l}\text { AA } \\
\text { AA }\end{array}$ & $\begin{array}{l}\text { A } 1 r-A c e t \\
\text { A } 1 r \text {-Acet }\end{array}$ & 2) & $50 \lambda$ sample $+10 \mathrm{ml}$ I\& La. \\
\hline $\begin{array}{l}\text { Sodium } \\
\text { Potassium } \\
\text { Iron }\end{array}$ & $\begin{array}{l}5890 \\
7665 \\
2483\end{array}$ & $\begin{array}{l}\text { AA } \\
\text { AA } \\
\text { AA }\end{array}$ & $\begin{array}{l}\text { Alr-Acet } \\
\text { Alr-Acet } \\
\text { Alr-Acet }\end{array}$ & 3) & $250 \lambda$ sample $+10 \mathrm{ml} \mathrm{H}_{2} \mathrm{O}$. \\
\hline Strontium & 4607 & $\mathrm{AA}$ & $\mathrm{N}_{2} \mathrm{O}-$ Acet & 4) & 4-ml sample $+1 \mathrm{ml} 58 \mathrm{La}$. \\
\hline $\begin{array}{l}\text { Manganese } \\
\text { Nickel } \\
\text { Cobalt } \\
\text { Lead } \\
\text { Copper } \\
\text { Chromium } \\
\text { Zınc }\end{array}$ & $\begin{array}{l}2795 \\
2320 \\
2407 \\
2170 \\
3247 \\
3579 \\
2139\end{array}$ & $\begin{array}{l}\text { AA } \\
A A \\
A A \\
A A \\
A A \\
A A \\
A A\end{array}$ & $\begin{array}{l}\text { A } 1 r-A c e t \\
\text { A } 1 r-A c e t \\
\text { A } 1 \text {-Acet } \\
\text { A } 1 r-A c e t \\
\text { A } 1 r-A c e t \\
\text { A } r-A c e t \\
\text { A } 1 r-A c e t\end{array}$ & 5) & $\begin{array}{l}\text { Sample read direct using } \\
\text { blank and standards with } \\
\text { matrix similar to samples. }\end{array}$ \\
\hline $\begin{array}{l}\text { Barlum } \\
\text { Rubidium } \\
\text { Titanium }\end{array}$ & $\begin{array}{l}5535 \\
7800 \\
3643\end{array}$ & $\begin{array}{l}\text { AA } \\
\text { AA } \\
\text { AA }\end{array}$ & $\begin{array}{l}\mathrm{N}_{2} \mathrm{O} \text {-Acet } \\
\mathrm{A}_{1} \text {-Acet } \\
\mathrm{N}_{2} \mathrm{O} \text {-Acet }\end{array}$ & 6) & $\begin{array}{l}\text { I ml } 108 \mathrm{KCl}+10-\mathrm{ml} \text { sample. } \\
\text { Potassium-contalning blank } \\
\text { necessary for } \mathrm{Rb} \text {. }\end{array}$ \\
\hline $\begin{array}{l}* A A \\
\star \quad A 1 r-A c e t\end{array}$ & $\begin{array}{l}\text { atomic } \\
\text { alr ace }\end{array}$ & to & - & ous & oxıde-acetylene. \\
\hline
\end{tabular}

Aluminum and Silicon

One ml of sample solution and $500 \mu l$ of 10 percent $\mathrm{KCl}$ were added to $10 \mathrm{ml}$ of deionized water and compared with 
aqueous silicon and aluminum standards using a nitrous oxideacetylene flame.

\section{Calcium and Magnesium}

Fifty $\mu 1$ of sample were added to $10 \mathrm{ml}$ of 1 percent lanthanum solution. The sample was compared with appropriate standards using an air-acetylene flame. Occasionally with this dilution the magnesium concentration was so high that it necessitated turning the burner several degrees to reduce the absorbance. Larger-concentration Mg standards were also used in this case so that the standard concentration would bracket the samples. In all cases a lanthanum blank was used.

Sodium, Potassium, and Iron

Two hundred fifty $\mu l$ of sample were added to $10 \mathrm{ml}$ of deionized water in a plastic vial. To prevent crosscontamination, the dilution was first analyzed for sodium-then for potassium and iron. Either flame emission or absorption may be used for sodium; only absorption is used for potassium and iron. For sodium and potassium analyses, a blank and standards were prepared containing the same amount of $\mathrm{LiBO}_{2}$ as would be present in the samples. This enables correction for the slight sodium and potassium contamination found in reagent grade $\mathrm{LiBO}_{2}$. Sodium, like magnesium, was often found to be excessively high in concentration for this dilution size--thus the optical path through the burner was shortened by turning the burner several degrees to reduce the absorbance.

\section{Strontium}

Four ml of sample were mixed with $1 \mathrm{ml}$ of 5 percent lanthanum solution and compared with appropriate standards using an $\mathrm{N}_{2} \mathrm{O}$-acetylene flame. 
Manganese, Nickel, Cobalt, Lead, Copper, Chromium, and Zinc

These elements were determined by directly aspirating the sample solution into an air-acetylene flame. They were compared with a specially-prepared trace element standard. This standard contained all of the trace elements in question in a solution matrix similar to an actual sample solution. A blank solution was prepared which was also similar to a typical sample, but contained no trace elements. The composition of the blank was $500 \mathrm{ppm}$ silicon, $250 \mathrm{ppm}$ iron, $130 \mathrm{ppm}$ aluminum, $50 \mathrm{ppm}$ sodium, $120 \mathrm{ppm}$ calcium, $30 \mathrm{ppm}$ titanium, $10 \mathrm{~g} /$ liter lithium metaborate, and 1.2 molar $\mathrm{HCl}$ (10 percent). The trace element standard was of the same composition; but in addition contained $0.5 \mathrm{ppm} \mathrm{Zn}, 2.5 \mathrm{ppm} \mathrm{Mn}, 0.5 \mathrm{ppm} \mathrm{Cu}, 0.5 \mathrm{ppm}$ $\mathrm{Ni}, 0.5 \mathrm{ppm} \mathrm{Cr}, 0.5 \mathrm{ppm} \mathrm{Pb}$, and $0.5 \mathrm{ppm} \mathrm{Co}$. It was found that the special blank matrix was necessary because of a slight absorbance that occurred even in the absence of the element in question. This slight absorbance is thought to be due to flame interference from the complex, high-salt sample matrix.

Ultra-Low Concentrations of Nickel, Cobalt, Copper, and Lead

Nickel, cobalt, copper, and lead concentrations were often near the detection limit of the instrument. It was found that these elements could be concentrated about 15-fold with limited success, utilizing a method similar to that described by Sachdev and West. (5) They describe the determination of seven trace metals by extraction of the dithizone chelate into ethyl propionate from aqueous solutions. The use of basaltic rock solution, however, necessitated a preliminary separation of the large amount of iron present from the solution since iron formed a heavy chelate precipitate with dithizone. This tended to interfere with chelation and extraction of the trace elements. Making a solution of $5.5 \mathrm{M} \mathrm{HCl}$ and passing it through an anion-form ion exchange column solved the problem by 
adsorbing the iron and allowing the trace elements to pass.

A column of chloride-form anion exchange resin $3 / 4$ in. by 4 in. was pretreated with $5.5 \underline{M} \mathrm{HCl}$. Thirty $\mathrm{ml}$ of concentrated $\mathrm{HCl}$ were mixed with $50 \mathrm{ml}$ of fused sample solution and passed through the column. The effluent was collected and the column was washed with $75 \mathrm{ml}$ of $4 \underline{\mathrm{M}} \mathrm{HCl}$. The effluent was again collected and the combined effluents were added to a beaker. The sample $\mathrm{pH}$ was adjusted to 7.5 with concentrated $\mathrm{NH}_{4} \mathrm{OH}$. Ten ml of 0.1 percent dithizone in ethyl propionate solution were shaken with the sample for 5 minutes in a separatory funnel. After allowing the phases to separate, the organic layer was centrifuged. An 0.1 percent ethyl propionate blank was equilibrated by shaking with water at the same aqueous/ organic ratio that was used with the sample. The reference standard was prepared by adding 0.2 ppm spikes of $\mathrm{Co}, \mathrm{Cu}, \mathrm{Ni}$, and $\mathrm{Pb}$ to the blank solution described on page 9 ; with subsequent treatment being the same as the samples. The absorbances of $\mathrm{Co}, \mathrm{Cu}, \mathrm{Ni}$, and $\mathrm{Pb}$ of the sample were compared with the reference standard by aspiration of the organic layers directly into the flame.

Barium, Rubidium, and Titanium

One $\mathrm{ml}$ of 10 percent $\mathrm{KCl}$ was added to $10 \mathrm{ml}$ of sample. The sample was analyzed for barium and titanium with a nitrous oxide-acetylene flame. Atomic absorption rather than flame emission was used for rubidium analysis because of high spectral interferences encountered on basalt fusion solutions. For all determinations, a blank and standards of typical sample matrix were used similar to that described on page 9. Rubidium sensitvity, as previously noted with flame emission, was found to be highly enhanced by the presence of 0.5 percent potassium. Because a slight absorbance was noted due to the potassium, it was necessary to have an equal amount of potassium in the blank solution. 


\section{RESULTS AND DISCUSSION}

The concentration range of the various elements analyzed in the Atlantic Richfield Hanford Company water samples is shown in Table III. Also shown is the coefficient of variation for recovery of metals using the APDC-MIBK method. In all cases, the recovery of the metals from the aqueous with 2 percent APDC and MIBK was greater than 90 percent. Accuracy and precision were determined by spike additions to samples.

TABLE II I

CONCENTRATION RANGE AND COEFFICIENTS OF VARIATION OF WATER SAMPLES

\begin{tabular}{|c|c|c|c|c|}
\hline \multirow{2}{*}{ Element } & \multicolumn{2}{|c|}{$\frac{\text { Concentration Range }}{\mathrm{ppm}}$} & $\begin{array}{r}\text { Coefficient } \\
\text { of Variation } \\
\end{array}$ & $\begin{array}{l}\text { Leve1 } \\
\text { ppm }\end{array}$ \\
\hline & 0.179 & -11.75 & & \\
\hline Calcium & 1.1 & -20.0 & & \\
\hline Sodium & 47. & -234 & & \\
\hline Manganese & $<0.01$ & 0.09 & & \\
\hline Chromium & $<0.01$ & 0.03 & & \\
\hline Potassium & 3.30 & 7.85 & & \\
\hline Silicon dioxide & 21. & -109. & & \\
\hline Lithium & 0.009 & $-\quad 0.023$ & & \\
\hline Rubidium & $<0.01$ & 0.03 & & \\
\hline Aluminum & $<0.1$ & & & \\
\hline Strontium & $<0.05$ & & & \\
\hline Barium & $<0.08$ & & & \\
\hline Iron & 0.02 & 2.10 & $+4 \%$ & 0.075 \\
\hline Zinc & 0.003 & 0.35 & $\mp 8 \%$ & 0.01 \\
\hline Nickel & 0.006 & 0.040 & Ғ10\% & 0.075 \\
\hline Lead & $<0.01$ & 0.05 & $\mp 9 \%$ & 0.075 \\
\hline Cobalt & $<0.002$ & 0.030 & $\mp 5 \%$ & 0.075 \\
\hline Copper & $<0.0005$ & 0.006 & $\mp 8 \%$ & 0.05 \\
\hline Cadmium & $<0.0005$ & 0.009 & $\mp 5 \%$ & 0.02 \\
\hline
\end{tabular}

Besides the seven elements in water samples that were extracted into the organic (see page 5), it was shown that $\mathrm{Sb}, \mathrm{Hg}, \mathrm{Pd}, \mathrm{Ru}$, and $\mathrm{Rh}$ could also be extracted with greater than 90 percent recovery. Although these elements were never 
found to be present in the water samples, it is interesting to note that the APDC extraction is effective in quantitatively isolating twelve trace elements with only one extraction.

The $W-1$ and $B C R-1$ rock sample major elements results are shown in Table IV, page 13; and are in close accordance with the reported USGS values. $(6,7)$ The trace element results compared favorably with the USGS samples when the trace element blank and standards were used as described on page 9. The only serious discrepancy is the unexplainable high results obtained for zinc on the $\mathrm{W}-1$ samples.

In most cases the trace elements in the basaltic rocks were of high enough concentrations to preclude the use of the ethyl propionate extraction method. These elements were also only of limited interest to the geologists. Although the results obtained on the BCR-1 standard were quite consistent, higher than reported values were obtained in the case of copper and nickel. Cobalt and lead values checked well with the BCR-l reported results. Spiked samples showed $>95$ percent recovery for $0.1 \mathrm{ppm}$ spikes. The results obtained for the BCR-1 standard using this method are shown in Table $\mathrm{V}$, below.

TABLE $\checkmark$

TRACE ELEMENT RECOVERIES FOR BCR-1 STANDARD USING DITHIZONE-ETHYL PROPIONATE EXTRACTION

\begin{tabular}{llllr} 
& \multicolumn{2}{c}{ Found } & & \multicolumn{2}{c}{ Element } & Range & & \multicolumn{2}{c}{ Average - Range } \\
\cline { 2 - 2 } Cobalt & $35-50$ & & 36. & $(29-60)$ \\
Copper & $60-75$ & & 22.4 & $(7-33)$ \\
Nickel & $30-40$ & & 15. & $(8-30)$ \\
Lead & $17-29$ & & 18. & $(5-35)$
\end{tabular}

A typical report of results on basaltic flows is shown in Table VI, page 14. Note that Sample 205 was run in duplicate as a check on analytical precision and the results compare well. Note also the interesting variations in some of the major metals reported as oxides. 
TABLE IV

RESULTS OF REFERENCE STANDARD ANALYSES

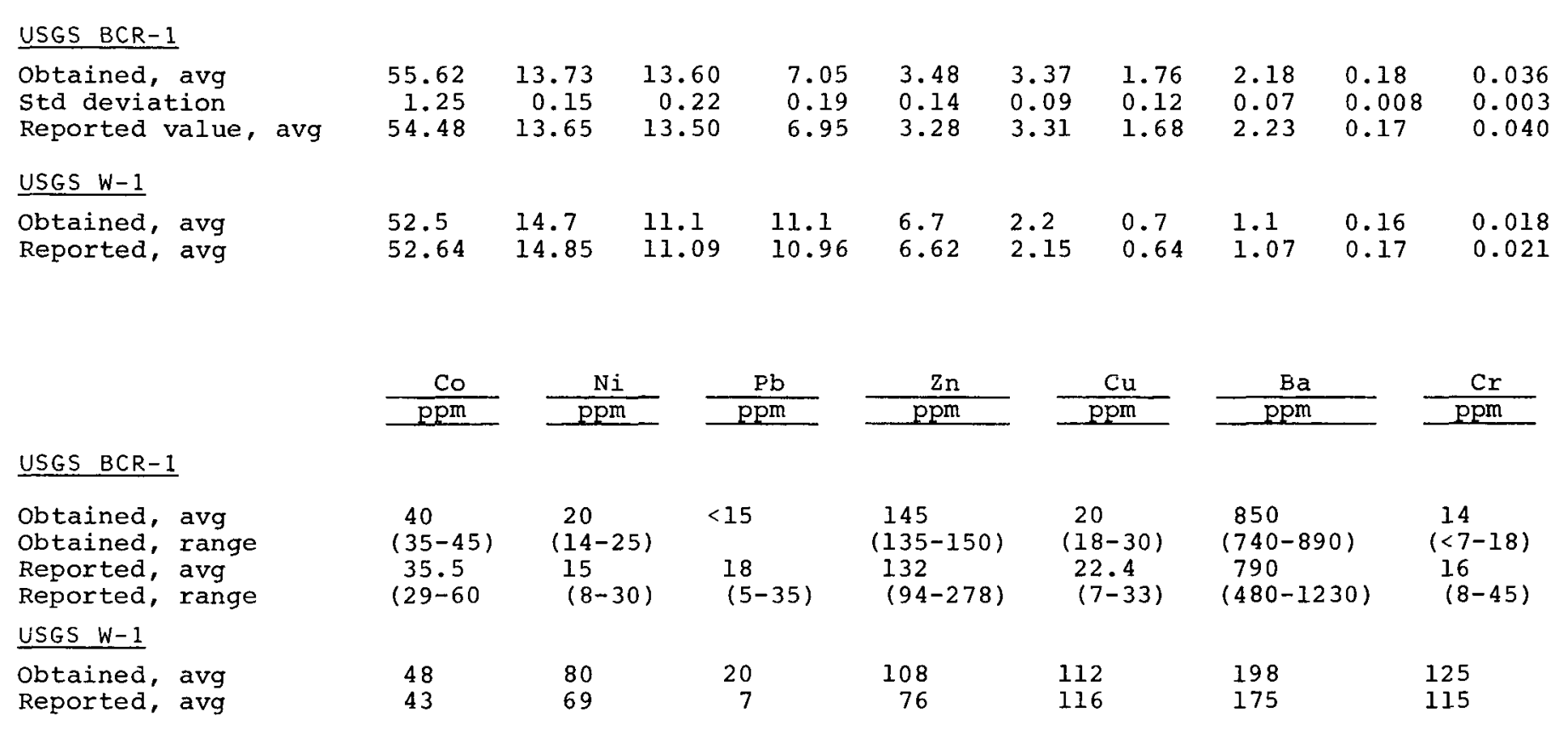


TABLE VI

TYPICAL BASALT RESULTS

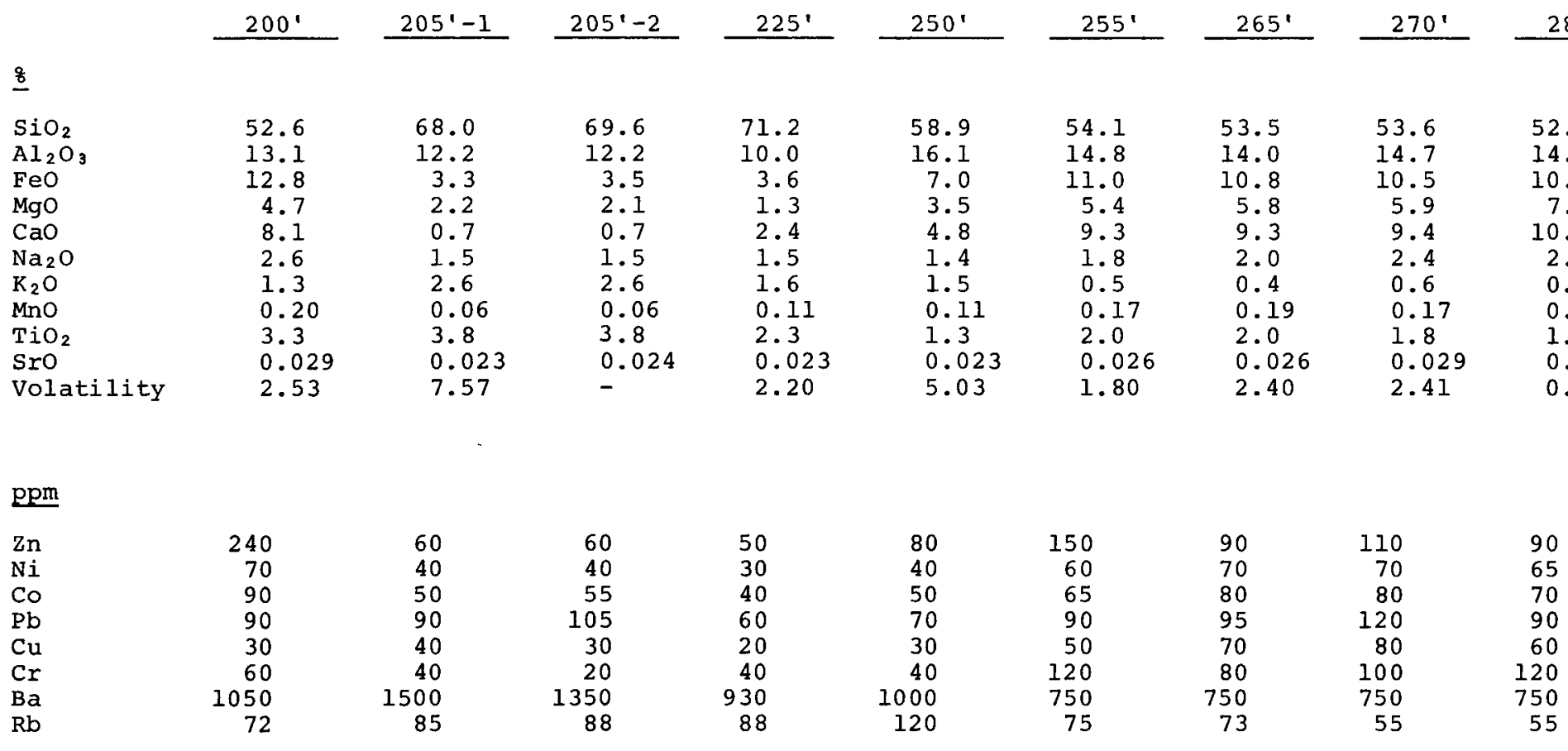




\section{ACKNOWLEDGMENTS}

The author wishes to express appreciation to M. H. Campbe11 and J. S. Buckingham for their editorial assistance; to Echo C. Gilmore and T. F. Dale for the laboratory work performed; and to Eleanore Earhart for her secretarial assistance.

\section{REFERENCES}

1. J. Remirez-Munoz. Atomic Absorption Spectroscopy, Elsevier Publishing Company, p. 270. (1968)

2. Ibid, p. 307 .

3. Ibid, p. 269 .

4. J. W. Yule and G. A. Swanson. Atomic Absorption News Zetter, vol. 8, No. 2, pp. 30-33.

5. S. Sachdev and P. West. "Concentration and Determination of Traces of Metal Ions," Analytica Chimica Acta, vol. 44, pp. 301-307. (1969)

6. M. Fleisher. United States Geological Survey Standards-I, "Additional Data on Rocks G-1 and W-1, 1965-1967," Geochimica et Cosmochimica Acta, vol. 33, pp. 65-79.

7. F. Flanagan. United States Geological Survey Standard-II, "First Compilation of Data for the New USGS Rocks" (BCR-I), Geochimica et Cosmochimica Acta, vol. 33, pp. 81-120. 
DISTRI BUT I ON

Number of Copies

87

Atlantic Richfield Hanford Company

D. I. Anderson

J. D. Anderson

S. J. Beard

L. I. Brecke

D. J. Brown

M. H. Campbe11 (10)

R. P. Corlew

G. L. Gurwell

J. M. Harnly

J. K. Hartwell

W. M. Harty

O. F. Hill

A. Holloway

R. E. Isaacson

L. M. Knights

M. J. Kupfer (10)

M. L. Madeen

C. W. Malody

G. C. Oberg

L. M. Richards

G. I. Ritter

W. W. Schulz

H. P. Shaw

J. A. Shurts

A. E. Smith

H. E. Smith

P. W. Smith

R. E. Smith

R. E. Tomlinson

J. H. Warren

N. S. Wing

W. I. Winters

ARHCO Document Control (2)

Extra (35)

Division of Technical Information Extension

Pacific Northwest Laboratory

Technical Information Library 
Number of Copies

14

Richland Operations Office

J. T. Christy

O. J. Elgert (10)

H. E. Parker

R. K. Sharp

Technical Information Library 